its

\section{Mr. Philip Lake}

PhimIP Lake, who died in Cambridge on June 12, was born on April 9, 1865, at Morpeth, where his father, George Lake, was headmaster of the Grammar School. On leaving school he became a student at the Durham/ Coge of Science, Newcastle upon Tyne, whare diforihterest in geology was aroused by the teh hiing of Prof. G. A. L. Lebour. He gained a schdiarship at St. John's College, Cambridge, in 1883 and was placed in the first class of both parts of the Natural Sciences Tripos (1886 and 1887) and was the first recipient of the newly founded Harkness Scholarship for geology. After taking his degree, Lake was appointed to the Geological Survey of India ; but for reasons of health resigned after three years and returned to Cambridge. In spite of his short period of service he was able to make some contributions to the geology of India.

This was a difficult period for young geologists, and for some years Lake held no appointment and was engaged in private tuition, examining and lecturing. In 1896 he became principal of the Colchester University Extension College, and spent one half of the week in Colchester and the other half in Cambridge. In 1908 Lake was appointed University lecturer in regional and physical geography at Cambridge, and in 1919 became reader in geography and head of the Department. At first there were few students, and the only accommodation was one room in the Sedgwick Museum and the use of a lecture room. The examinations qualified only for the ordinary degree until the Geographical Tripos was established in 1921. Owing to the excellence of Lake's teaching, which was based on wide learning and a sound knowledge of the physical sciences and mathematics, geography made rapid strides, and when he resigned in 1927 it had become a flourishing Depart. ment.

Under the title of "Text-book of Comparative Geology" (1893) Lake translated and edited E. Kayser's "Lehrbuch der geologischen Formationskunde". His "Physical Geography" (1915) met with immediate success, and is still a standard work. With R. H. Rastall he wrote a "Text-book of Geology" (1910), of which five editions have been published. He also contributed articles on regional geology to the "Encyclopedia Britannica". Between 1893 and
1912 Lake gave to the Geological Society the results of his research on the Lower Palæozoic formations of five districts in North Wales. He also wrote on the river system of Wales $(1900,1934)$, on hill slopes (1928), on mountain and island arcs (1931) and on Wegener's theory of continental drift (Geograph. J., $61 ;$ 1923). In palæontology, Lake was an authority on Trilobites and wrote on Acidaspis (1896), on Trilobites from Bolivia (1906) and from the Bokkeveld Beds of South Africa (1904). His main palæontological work was a monograph of British Cambrian Trilobites (Palæontograph. Soc., 1906-46). Much of the material for this was poorly preserved and needed patient and prolonged study. In this connexion Lake discovered a method of photographing which eliminated the distortion of the fossils and showed their original form (Geol. Mag., 1943). $\mathrm{He}$ was able to give the mathematical proof of this method (British J. Photography, 91; 1944).

Lake served on the Council of the Geological Society during 1904-7 and 1927-28, and was awarded the Lyell Medal of the Society in 1912. He was unmarried and outlived all his family and most of his contemporaries, so that his last years seemed somewhat lonely; but he maintained his interests and was always cheerful. By all who knew him he will be remembered as a most friendly and kind man, ever ready to help others.

H. Woods

WE regret to announce the following deaths :

Sir Rowland Biffen, F.R.S., emeritus professor of agricultural botany in the University of Cambridge, aged seventy-five.

Dr. Kudolf Hac, professor of analytical chemistry in the Prague Polytechnic, formerly of the Moravian Agricultural College, whose researches related to the use of thallium carbonate as a volumetric standard and to certain catalytic effects shown by molybdenum compounds, on March 16, aged sixty-six.

Sir Edwin Pascoe, director during 1921-32 of the Geological Survey of India, on July 5, aged seventy. one.

Prof. B. Sahni, F.R.S., professor of botany in the University of Lucknow, and honorary professor in the University of Benares, on April 9, aged fifty-seven.

\section{6}

Prof. C. S. Gibson, QR.E., F.R.S.

Prof. C. S. Gibson, tho is now vacating the chair of chemistry at Guys Hospital Medical School, has held it with of distinction since 1921. After working with Prof. W. J. (afterwards Sir William) Pope atpMaMthester and Cambridge, he went in 1912 to Indif as professor of chemistry in the University of Oradfas', but was back in England on war service in $\$ 15$, when he again collaborated with his old chief on problems of chemical warfare. After a short period as professor at the Medical School in Cairo, he succeeded Prof. T. M. Lowry as head of the chemistry department at Guy's Hospital Medical School. Always an enthusiastic research worker, Gibson maintained an impressive scientific output in spite of the fact that his students rarely specialized in chemistry. He secured considerable expansion of his department, found time to collaborate with his

\section{and VIEWS}

hospital colleagues on various professional problems and devoted considerable energy to studies of chemotherapeutic and dental materials.

Gibson's main scientific interests were in stereochemical problems; in the materials of chemical warfare; in certain natural products (working in collaboration with Sir John Simonsen); and in the chemistry of organic compounds of arsenic and of gold. His most striking successes were the direct method used in the First World War for producing mustard gas; his studies of the sternutatory compound phenarsazine chloride and related substances; and latterly his long series of investigations on the organo-gold compounds, based on an original observation with Pope in 1907. From this also emerged a method for the controlled production of gold films which has proved of considerable practical value. An active member of many scientific bodies, Gibson 